\title{
Traumatic avulsion of extraocular muscles: case reports
}

\author{
Avulsão traumática de músculos extraoculares: relatos de casos
}

Nilza Minguini ${ }^{1}$, Karin Suzete Ikeda ${ }^{2}$, Keila Monteiro de Carvalho 3

\begin{abstract}
We described the clinical, surgical details and results (motor and sensory) of the retrieving procedure of traumatically avulsed muscles in three patients with no previous history of strabismus or diplopia seen in the Department of Ophthalmology, State University of Campinas, Brazil. The slipped muscle portion was reinserted at the original insertion and under the remaining stump, which was sutured over the reinserted muscle. For all three cases there was recovery of single binocular vision and stereopsis
\end{abstract}

Keywords: Eye injuries; Oculomotor muscles/injuries; Strabismus/surgery;Diplopia; Depth perception; Case reports

\section{RESUMO}

Foram descritos os quadros clínicos, detalhes cirúrgicos e resultados (motores e sensoriais) da reinserção de músculos traumaticamente avulsionados, em três pacientes sem estória prévia de estrabismo ou diplopia, atendidos no Departamento de Oftalmologia da Universidade Estadual de Campinas. A porção muscular deslizada foi reinserida na linha da inserção original e sob o coto remanescente, o qual foi acomodado e suturado sobre o músculo reinserido. Para os três casos houve recuperação da visão binocular única e da estereopsia.

Descritores: Traumatismos oculares; Músculos oculomotores/lesões; Estrabismo/ cirurgia; Diplopia; Percepção de profundidade; Relatos de casos

\section{INTRODUCTION}

Extraocular muscle avulsion of traumatic etiology is not frequent ${ }^{(1,2)}$. The medial and inferior recti are the most frequently injured muscles. This has been explained by reflex reaction of up and out movement of the eye (Bells' phenomenon) when eye injury is threatening.

Chances of retrieving a transected muscle are higher in cases of trauma comparing to inadverted transaction during muscle surgery, as their attachments to other extraocular muscles and nearby tissues are often preserved ${ }^{(2)}$.

Excluding the medial rectus that lacks attachment to another muscle, an intact muscle disinserted by trauma will typically be located in a sufficiently anterior position for a standard transconjunctival approach with no need of orbitotomy ${ }^{(3)}$.

Preoperative high resolution $\mathrm{CT}$ scans with proper techniques and magnetic resonance imaging can identify the damaged muscle in detail. The oculocardiac reflex is also an effective aid in identifying the tissue as muscle, during repairing surgery ${ }^{(4)}$.

In this series, we describe the clinical and surgical findings, repairing technique and the surgical results from three patients that were admitted to University of Campinas Clinical Hospital, Brasil, victims of ocular trauma and consequent muscle disinsertion.

\section{CASE REPORT}

\section{CASE 1}

A 17-year-old female was victim of a dog bite in her left medial orbital region. Approximately two hours later, she came to the emergency room complaining of double vision and limitation of movement of her left eye. She had no previous history of strabismus or ambliopia. Examination on presentation revealed visual acuities of 20/20 in her right eye and 20/50 in her left eye. The patient had a large angle left exotropia and loss of left adduction. A tendon stump of approximately $2.5 \mathrm{~mm}$ could be observed through a medial bulbar conjunctival laceration. A retinal hemorrhage and a laceration of inferior lacrimal canaliculus were also noted. On surgical exploration rupture of the globe was not found. The lost medial rectus muscle could be located when oculocardiac reflex was observed with traction of the suspected tissue located at the equator. The tissue was then sutured at its original insertion point under the preserved tendon stump which was then blended and sutured over the reinserted muscle. The conjunctiva and lacrimal lacerations were also repaired. One week later alignment was straight in all positions of gaze with no limitation on ductions or versions. No double vision was present and a stereoacuity of 40 seconds of arc was measured. Retinal treatment was not necessary and visual acuity had normalized. (Figure 1).

\section{CASE 2}

A 50-year-old, presented with exodeviation of the left eye, which suddenly developed after her face was struck with a suspended hook three hours previously. Visual acuity of this eye was reduced to 20/50 and adduction was severely limited. A $10 \mathrm{~mm}$ long, crescent-shaped, wound was seen in the medial conjunctiva and it was apparent that the medial rectus had been avulsed. At surgery it was possible to localize and relocate the snapped muscle with the aid of oculocardiac reflex and using the same technique as in case 2. Motility and senso-
Submitted for publication: March 18, 2013

Accepted for publication: May 23, 2013

Study carried out at Universidade Estadual de Campinas - Unicamp - Campinas (SP), Brazil.

Assistant Physician, Department of Ophthalmology and Otorhinolaryngology, Faculty of Medical Sciences, Universidade Estadual de Campinas - Unicamp - Campinas (SP), Brazil.

Ophthalmologist and postgraduate student, Department of Ophthalmology and Otorhinolaryngology, Faculty of Medical Sciences, Universidade Estadual de Campinas - Unicamp - Campinas (SP), Brazil.

${ }^{3}$ Professor, Department of Ophthalmology and Otorhinolaryngology, Faculty of Medical Sciences, Universidade Estadual de Campinas - Unicamp - Campinas (SP), Brazil.
Funding: No specific financial support was available for this study

Disclosure of potential conflicts of interest: N.Minguini, None; K.S.Ikeda, None; K.M.Carvalho; None Correspondence address: Nilza Minguini. Departamento de Oftalmo/ORL - Hospital de Clínicas Unicamp. Rua Vital Brasil, 251 - Campinas (SP) - 13083-888 - Brazil

E-mail: minguini@uol.com.br

Research Ethical Commmittee, Universidade Estadual de Campinas - Unicamp, Campinas (SP), Brazil. Pratocol: no 013/2012 


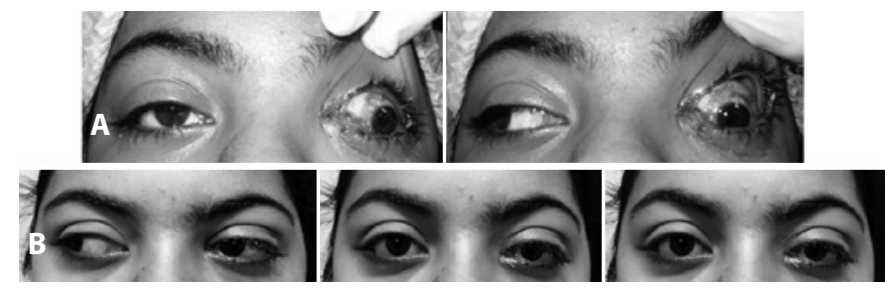

Figure 1. Case 1 - Preoperative exotropia in primary position and limitation of adduction of the left eye (A). The same patient seven days after surgery (advancing the left medial rectus) showing no limitation of left eye adduction (B).

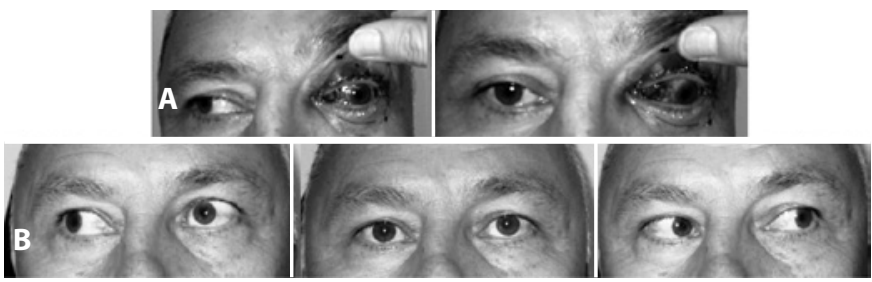

Figure 2. Case 2-Preoperative exotropia in primary position and limitation of adduction of the left eye (A). The same patient at sixty days after surgery (advancing the left medial rectus) showing a residual limitation of left eye adduction (B).

rial results were satisfactory. Although a moderate limitation of left eye adduction had persisted, primary position alignment and normal stereoacuity were recovered (Figure 2).

\section{CASe 3}

A 58-year-old woman presented to the State University of Campinas Clinical Hospital complaining of double vision with a history of trauma in her right eye caused by a hook of a wire coat-hanger. On examination, best-corrected visual acuity was 20/40 in the right eye and 20/25 in the left. She had no history of strabismus or double vision before this accident. In primary position, the right eye was hypertropic and the infraduction of this eye was almost absent. A inferior bulbar conjunctival laceration was diagnosed and it became apparent that the inferior rectus muscle had been avulsed near its insertion, because there were $3 \mathrm{~mm}$ of tendon hanging loose from the scleral insertion. No retinal lesions or hemorrhages were noted. The intraocular pressure was normal and rupture of the globe was considered unlikely. At surgery, performed 24 hours after the accident, the proximal portion of the muscles could not be easily found. No ocular-cardiac reflex was presented when traction was done on any suspected tissue, except when the inferior oblique was hooked. Then, amounts of lacerated and swollen tissues above the inferior oblique were brought to the inferior rectus insertion and sutured bellow the remaining portion of tendon with 6-0 Vicryl ${ }^{\mathrm{TM}}$. The tendon stump was blended and sutured over the supposed newly sutured muscle belly. At two weeks of follow up, motility examination showed that depression was normalized, but a slight limitation of elevation was found. No double vision was present in primary and down gaze positions. Visual acuity was bilaterally normal. Stereoacuity of 40 seconds of arc was measured. Further surgery for repairing reduced palpebral fissure has been rejected by the patient (Figure 3).
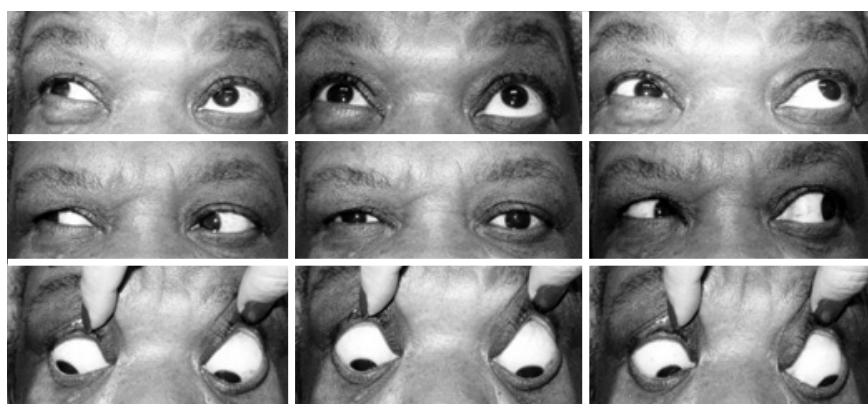

Figure 3. Case 3 - Patient at two weeks of follow-up. Motility examination showing normalized depression and a slight limitation of elevation. The reduced right palpebral fissure can be observed.

\section{DISCUSSION}

A severed nerve to an extraocular muscle, or a crushed muscle must always be considered as differential diagnosis of a transected muscle in cases of strabismus due to ocular trauma. In this series, tendon stumps at the insertion sites were incontestable evidences of the right diagnosis rationale.

Certainly, the surgical technique employed in this series, as it had resembled a resection procedure, had induced a change in both load and length/tension muscle properties. However, there must have been a muscle adaptation which can explain the efficacy of the procedures for the three reported cases, all of them ending up with maximal grade of stereopsy.

The time limit during which a muscle may be recovered with good function is unknown ${ }^{(5,6)}$. Wright had suggested that the procedure should be done as soon as 7 to 10 days after the traumatic event ${ }^{(5)}$. In this series, the surgeries were performed at 1 to and 3 days after trauma, fact that should have corroborated the good sensorial and motor results.

There were not requested imaging studies for the patients of this series. Some authors feel diagnostic imaging do not need to be done routinely for cases of slipped or lost muscles ${ }^{(7)}$. In agreement with them, we also consider that these tests did not prove to be essential for the cases reported, since clinical signs were considered sufficient for surgical planning.

\section{REFERENCES}

1. Plagger DA, Parks MM. Recognition and repair of the "lost" rectus muscle. A report of 25 cases. Ophthalmology. 1990;97(1):131-6.

2. MacEwen CJ, Lee JP, Fells P. Aetiology and management of the 'detached' rectus muscle. Br J Ophthalmol. 1992;76(3):131-6.

3. Knapp P. Lost muscle. In: Symposium on strabismus: transactions of the New Orleans Academy Ophthalmology. St Louis: CV Mosby; 1978. p.301-6.

4. Apt L, Isenberg SJ. The oculocardiac reflex as a surgical aid in identifying a slipped or 'lost' extraocular muscle. Br J Ophthlamol. 1980;64(5):362-5.

5. Wright KW. Discussion. Ophthalmology. 1990; 97(1):136-7. [discussion on: Plagger DA, Parks MM. Recognition and repair of the "lost" rectus muscle. A report of 25 cases. Ophthalmology. 1990;97(1):131-6].

6. Underdahl JP, Demer JL, Goldberg RL, Rosembaum AL. Orbital wall Approach with preoperative orbital imaging for identification and retrieval of lost or transected extraocular muscles. J AAPOS. 2001;5(4):230-7.

7. Greenwald MJ, Ticho BH, Engle JM. Extraocular muscle surgery. In Krupin T: Atlas of Complications of Ophthalmic Surgery. London: Wolfe; 1993. p.11-5. 